\title{
$\mathrm{SiC}$ 粒子強化 AC4B 合金複合材料の回転曲げ疲労特性に 及ぼす切欠きおよび組織の影響*1
}

\author{
丸野祐策*2 三村直也*2 宮原広郁 大城桂作
}

九州大学大学院工学研究院材料工学部門

J. Japan Inst. Metals, Vol. 70, No. 7 (2006), pp. 554-561

(C) 2006 The Japan Institute of Metals

\section{Influence of Notch Size and the Solidification Microstructure on the Rotating Bending Fatigue Characteristics of SiC Particle-Reinforced AC4B Alloy Composites}

\author{
Yusaku Maruno*2, Naoya Mimura*2, Hirofumi Miyahara and Keisaku Ogi \\ Department of Materials Science \& Engineering, Kyushu University, Fukuoka 819-0395
}

\begin{abstract}
The influence of the surface notch size, the $\mathrm{SiC}$ particle distribution and the solidification microstructure of the matrix on the fatigue characteristics were investigated, and the parameter governing fatigue was evaluated for SiC particle-reinforced JISAC4B alloy composites. 10 to $30 \%$ vol $11 \mu \mathrm{m} \mathrm{SiC}$ particles were relatively homogeneously dispersed in an Al-6.79\% mass Si$2.93 \%$ mass $\mathrm{Cu}-0.17 \%$ mass $\mathrm{Mg}-0.59 \%$ mass $\mathrm{Fe}$ matrix alloy through a combination of pressure infiltration and melt stirring casting technique. The matrix microstructure consists of a dendritic alpha phase and eutectic structure. A few intermetallic Fe compounds were observed in the dendritic alpha phase. Furthermore, all composite specimens contained $\mathrm{SiC}$ particle clusters. Vickers hardness of composites increased due to the dispersion of $\mathrm{SiC}$ particles and age hardening effect, and the hardening ability increased with an increase in the volume fraction of $\mathrm{SiC}$ particles. Rotating bending fatigue tests were carried out on both notch-free and notched specimens that were aged to reach their peak hardness. When the stress concentration factor was low, cracks generated from cast defects in the matrix alloy specimen. On the contrary, they generated in boundaries between the $\mathrm{SiC}$ particles and the matrix in the composite specimens. Furthermore, the fatigue strength decreased with an increase in the $\mathrm{SiC}$ volume fraction. For the notched matrix specimen, in which the stress concentration factor is high, the notch size governed the fatigue strength. However, the cracks generated from the boundaries near $\mathrm{SiC}$ particles instead of the notch base in the notched composite specimen. Moreover, it was found that the fatigue limit stress is unchanged in the composite specimen even when the notch is introduced, although the critical stress for crack generation is reduced. Microstructural observations revealed that the cracks are spread and diverted in and around clusters of $\mathrm{SiC}$ particles. This suggests that crack propagation resistance is improved by the $\mathrm{SiC}$ particles in the notched composite specimen.
\end{abstract}

(Received January 30, 2006; Accepted May 18, 2006)

Keywords: cast composites, notch, solidification, non-propagating crack, crack generation stress, fatigue limit stress

\section{1. 緒言}

近年，自動車などの輸送機械および各種産業機械分野にお いて, 強度, 耐熱性, 耐摩耗性の向上の要求に応える新素材 として, アルミニウム合金中にセラミックス粒子を分散させ た複合材料の開発が進められている. SiC 粒子は高硬度で剛 性が高く, かつ高温安定性, 耐摩耗性, 耐熱衝撃性にも優 れ, アルミナやボロン繊維より濡れ性がよく, 比較的安価で あることから，アルミニウム合金の強化材として適している と考えられる1-3). $\mathrm{SiC}$ 粒子分散 $\mathrm{Al}$ 合金系複合材料の製造法 としての鋳造法は, 複合温度は比較的高いが複合化時間が短 く, 二次加工の必要性が少ないため, 特に複雑形状品の生産 に優れると思われる ${ }^{4,5)} . \mathrm{SiC} / \mathrm{Al}$ 合金複合材料の機械的性質 については, 引張強度をはじめ剛性, 耐摩耗性等が報告され

\footnotetext{
*1 Mater. Trans. 46(2005) 950-958 に掲載

*2 九州大学大学院生, 現在 : 侏日立製作所 (Graduate Student, Kyushu University, Present address: Hitachi, Ltd.)
}

ているが6), 疲労特性については比較的少なく7,8), また鋳造 試料については極めて少ない9,10).さらに, 鋳造品はその表 面は砂型または金型を転写しており，細かい凹凸が存在して 切欠きとして機械的性質を低下させると考えられるが, 鋳造 複合材料の疲労特性について切欠きを評価した報告はほとん ど無い.

そこで本研究では, 自動車用エンジンブロック等に利用さ ている JIS-AC4B 合金を母合金とし，加圧溶浸法および溶 湯攪拌法を組み合わせて, $\mathrm{SiC}$ 粒子を $10 \sim 30 \mathrm{vol} \%$ の体積率 で複合化することを試みた。続いて得られた複合材料につい て疲労特性を調査し, 凝固組織, 粒子体積率および粒子の分 布状態との関係を調査するとともに, 切欠きを人工的に付与 し, 疲労き裂発生および伝ぱに及ぼす切欠きの影響を評価し た。

\section{2. 実 験 方 法}

強化材として平均粒子径が $11 \mu \mathrm{m}$ の $\mathrm{SiC}$ 粒子 (Fujimi In- 
corporated Company Co. Ltd., 不純物 : 0.63 mass $\% \mathrm{SiO}_{2}$, $0.36 \mathrm{mass} \% \mathrm{C}$ (以後\%と略記する))を，またマトリックス合 金には JIS-AC4B 合金 $(\mathrm{Al}-6.79 \% \mathrm{Si}-2.93 \% \mathrm{Cu}-0.17 \% \mathrm{Mg}-$ $0.49 \% \mathrm{Mn}-0.59 \% \mathrm{Fe}-0.17 \% \mathrm{Zn})$ を用いた。任意の体積率を 有する複合材料を得るため, 加圧溶浸法および溶湯攪挥法を 組み合わせて用いた。加圧装置は金型, 加圧シリンダおよび コントローラから構成されて抢り，一般に鋳造複合材料内の 気孔が圧着されるとされている $50 \mathrm{MPa}$ まで加圧できる。一 方，溶湯攪拌装置は，電気炉，覺汼子および温度制御部から 構成されており，フラックスおよび $\mathrm{Ar}$ ガスにより溶湯表面 の酸化物等を除去して金属表面の清浄化を図ることができ る。実験はまず，AC4B 合金を黒鉛るつぼで $1073 \mathrm{~K}$ に加 熱・溶解し, 一方 $\mathrm{SiC}$ 粒子はアルミナるつぼで $873 \mathrm{~K}$ に予 熱した．加圧装置にあらかじめ設置した金型に予熱 $\mathrm{SiC}$ 粒 子を充填した後, 溶融 $\mathrm{AC} 4 \mathrm{~B}$ 合金を鋳込み, 直ちに $50 \mathrm{MPa}$ の圧力で凝固が完了すると考えられる 3 分間加圧した. 得 られた試料の $\mathrm{SiC}$ 体積率はおよそ $50 \mathrm{vol} \%$ であった。続い て, 得られた複合試料と AC4B 合金を用いて, 所定の粒子 体積率となるように攪拌装置により混合した。攪拌速度が速 い場合, 遠心力によりるつぼの壁面に粒子が偏在し, 一方, 遅い場合は粒子が沈降する傾向があるので, 攪汼条件は予備 実験結果を基に $60 \mathrm{rpm}$ で 60 分間とした。覺拌後，共晶 $\mathrm{Si}$ の改良材として溶湯の $300 \mathrm{ppm}$ 相当量の $\mathrm{Al}-10 \% \mathrm{Sr}$ 母合金 を添加し, 溶湯温度約 $935 \mathrm{~K}$ で 10 分間沈静化し, 試料全体 を金型へ注湯し, 再び $50 \mathrm{MPa}$ で加圧鋳造した. 得られた鋳 造複合材料加縦 $10 \mathrm{~mm}$, 幅 $10 \mathrm{~mm}$, 長さ $62 \mathrm{~mm}$ の試験 片を切り出し, $773 \mathrm{~K}$ の塩浴中で $10 \mathrm{hr}$ の溶体化処理を行 い, 水水中に焼入れた. 引き続き $433 \mathrm{~K}$ のシリコン油浴中 で $30 \mathrm{~min}$ から $10^{4} \mathrm{~min}$ (約 1 週間) までの所定時間ごとの時

(a)
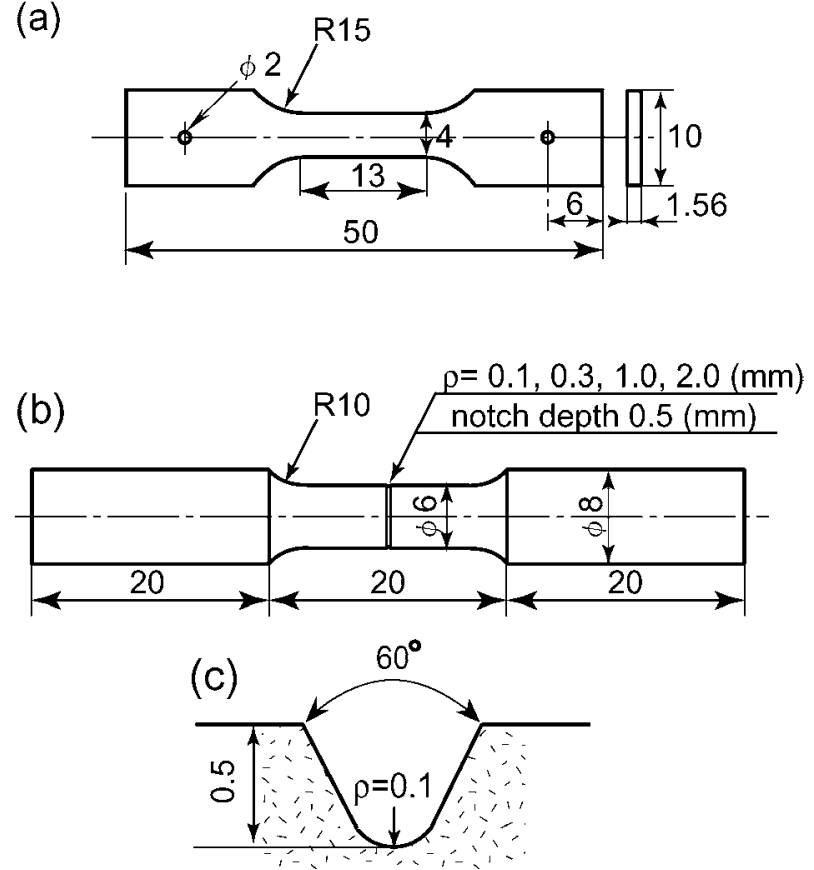

Fig. 1 Schematic view of the test pieces for the notch-free tensile strength test (a) and the fatigue test (b) with and without V-form notch (c).
効処理を施し急冷した.

荷重 $20 \mathrm{kgf}$ 抢よび $50 \mathrm{gf}$ で $30 \mathrm{~s}$ 保持してマクロおよびミ クロビッカース硬さを測定し，得られた時効処理材料のうち 最高硬さを示した試料を Fig. 1 に示す引張試験片および疲 労試験片形状に加工した. 疲労試験試料の表面は, 平滑面の ままのものと, 深さ $0.5 \mathrm{~mm}$, 曲率半径 $\rho=0.1 \mathrm{~mm}$ の $60^{\circ} \mathrm{V}$ 形切欠きを人工的に付与し， $3 \mu \mathrm{m}$ のアルミナ粒子および 1 $\mu \mathrm{m}$ のダイヤモンドペーストで表面を鏡面仕上げしたものを 準備した. 疲労試験は小野式回転曲げ疲労試験機 (曲げモー メント $15 \mathrm{~N} \cdot \mathrm{m}$, 回転数 $50 \mathrm{~Hz}$ )を用い, 両振り正弦波, 応 力比 $R=-1$ の条件で実験を行った. 試料に加える応力 $(\sigma)$ は最小断面に打ける公称応力を用い, $\sigma=5 \sim 10 \mathrm{MPa}$ ずつ変 化させた各応力において破断するまでの応力繰返し数 $(N)$ を測定した。なお， $N$ が $10^{7}$ 回を越えた試験片については破 断しないものとみなして試験を終了した。 すなわち, 本実験 では $N=10^{7}$ の繰返しに耐える応力を疲労限度と定義した。 得られた各試験片の切欠き底部の停留き裂は光学顕微鏡およ びSEM により観察し, 疲労特性に及ぼす凝固組織の影響を 評価した。

\section{3. 実験結果および考察}

\section{$3.1 \mathrm{SiC} / \mathrm{AC} 4 \mathrm{~B}$ 複合材料の組織観察}

Fig. 2 に溶体化処理後 $433 \mathrm{~K}$ でピーク時効させた複合材 試料の組織を示す. $\mathrm{SiC}$ 粒子体積率は，いずれの試料も 9.3 および $31.4 \mathrm{vol} \%$ と目的とする 10 および $30 \%$ に近く(以後 9 vol\%試料， $31 \mathrm{vol} \%$ 試料と略記する)，また，粒子はマトリ ックス全体に比較的均一に分布していた. しかしながら, 数 百ミクロンごとの比較的長距離周期に離れた凝集部と数ミク ロン程度の間隔で凝集した領域が観察された. 前者は, 溶湯 攪拌が不十分であったためと考えられ, 後者はデンドライト 状の初晶 $\alpha$ 相が $\mathrm{SiC}$ 粒子を避けて成長した結果と思われ る. マトリックスの凝固組織は初晶 $\alpha$ 相, 共晶 $\mathrm{Si}$ 相, 抢よ び Fe 化合物相 $\left(\alpha-\mathrm{Al}_{15}(\mathrm{Fe}, \mathrm{Mn})_{3} \mathrm{Si}_{2}\right.$ および $\left.\beta-\mathrm{Al}_{5} \mathrm{FeSi}\right){ }^{11)}$ か らなっているが，Fig. 2(c) に示すように $\mathrm{SiC}$ 粒子に接触し ている Fe 化合物相は, 他の場合よりやや粗大に成長してい た．な抢，いずれの合金中にも $5 \sim 150 \mu \mathrm{m}$ 程度のブロー ホールやミクロシリンケージが残っていた.

\section{2 複合材料の時効硬化挙動}

Fig. 3 に 9 vol\%抢よび 31 vol\%試料の 433 K に打りる時 効硬化曲線を示した。な拈中には比較材としてマトリック ス合金の結果も示した、マトリックス合金では一般の場合と 同様に，溶体化処理後の急冷により一度硬化し，433 K 保持 により軟化および時効硬化した. Fig. 3(a)に示すように, マクロ硬さは溶体化処理時に対して $840 \mathrm{~s}$ でおよそ $30 \mathrm{HV}$ 上昇し， $145 \mathrm{HV}$ の最高硬さまで到達した。複合材料におい ても同様に，溶体化処理により硬さの上昇がみられたが，こ れは $\mathrm{Al}_{2} \mathrm{O}_{3} / \mathrm{AC} 4 \mathrm{~B}$ 合金 ${ }^{11-13)} \mathrm{SiC} / \mathrm{Al}$ 合金 ${ }^{14,15)}$ 等にも報告され るように，急冷時に粒子/マトリックス間の熱膨張係数差に よる急冷時での転位の導入の影響もあると考えられる. 時効 の進行に伴い時効硬化するが，ピーク時効に達する時間はマ 

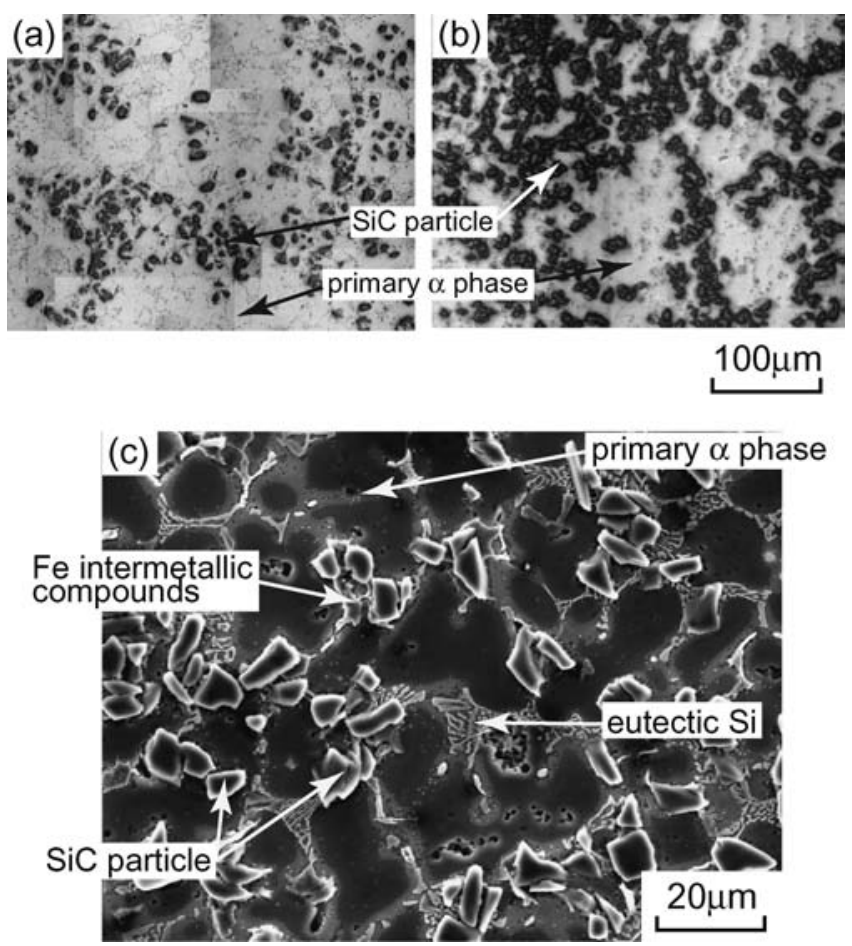

Fig. 2 Microstructure of the composite specimens containing $\mathrm{SiC}$ particles of $9.3 \%$ (a) , and $31.4 \%$ (b, c) in volume observed by optical microscope (a, b) and SEM (c).

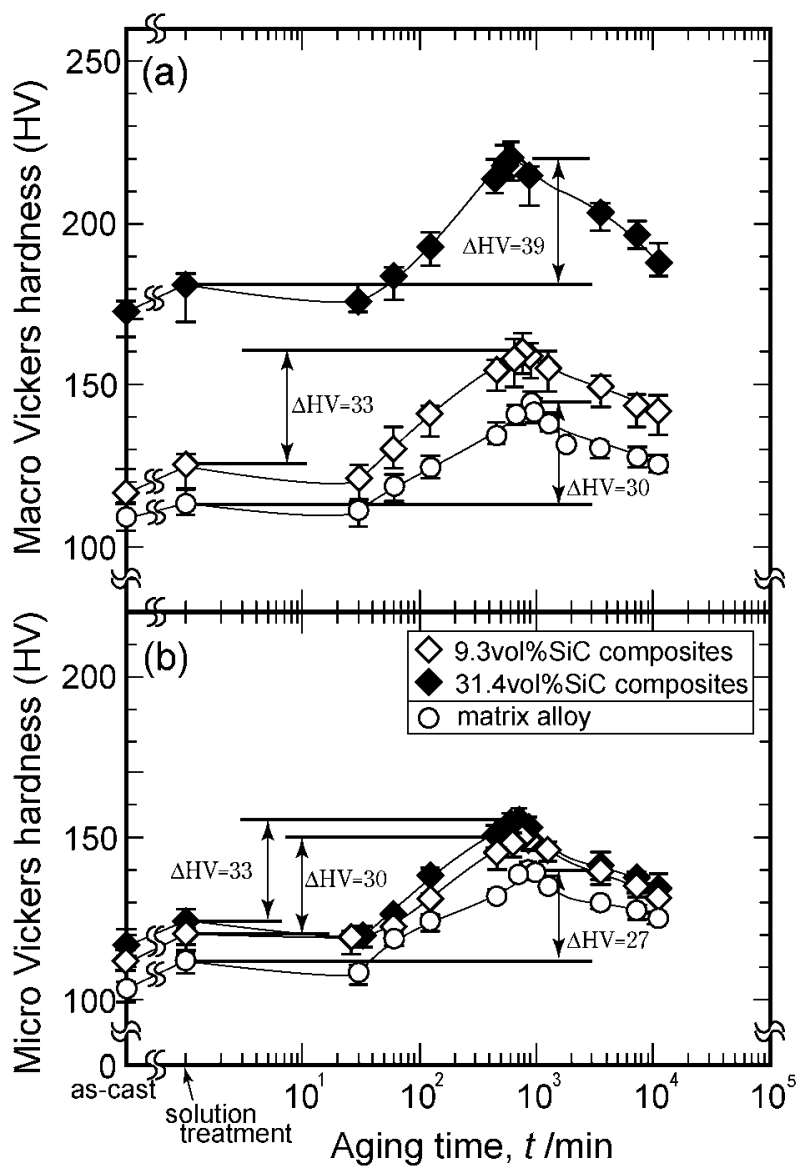

Fig. 3 Variation of macro- Vickers hardness at a stress of 20 $\mathrm{kg}$ (a) and micro- Vickers hardness at $50 \mathrm{~g}$ (b) as the function of aging time at $443 \mathrm{~K}$ for 9.3 and $31.4 \mathrm{vol} \% \mathrm{SiC} / \mathrm{AC} 4 \mathrm{~B}$ alloy composites.
トリックス合金試料の場合より早く, $9 \mathrm{vol} \%$ 試料は最大硬 さも $159 \mathrm{HV}$ となり $33 \mathrm{HV}$ 上昇した. $31 \mathrm{vol} \%$ 複合材料にお いても同様な挙動を示したが，ピークに達する時間は 660 s, その時の最高硬さは $220 \mathrm{HV}$ と $9 \mathrm{vol} \%$ 試料より変化量が 大きくなった. すなわち Fig. 4 に示したように, as-cast 時, 溶体化後およびピーク時の硬さは $\mathrm{SiC}$ 体積率の上昇と ともに増加し, 一方, ピーク時効の到達時間は短縮した.こ れはマトリックス合金と $\mathrm{SiC}$ 粒子との熱膨張係数の差によ り導入された転位が時効に寄与する $\lambda^{\prime}$ 相 $\left(\mathrm{Al}_{5} \mathrm{Cu}_{2} \mathrm{Mg}_{8} \mathrm{Si}_{8}\right)$ ， $\theta^{\prime}$ 相 $\left(\mathrm{Al}_{2} \mathrm{Cu}\right)$ 等の析出を助長したためと考えられた ${ }^{11)}$. なお Fig. 3 (b)に示すように $\mathrm{SiC}$ 粒子から離れたデンドライト中 心におけるミクロ硬さについては, 未複合材料の最大硬さ $140 \mathrm{HV}$ に対して $31 \mathrm{vol} \%$ 試料では $155 \mathrm{HV}$ までしか上昇せ ずその差は小さかった。よって複合試料のうち粒子から離れ た領域では粒子の影響が少なく，マトリックス合金と同様の 時効硬化曲線を示したと思われる．以上，それぞれ最高マク 口硬さを示した条件で試料を作製し, 以後の引張試験および 疲労試験に供した.

\section{3 引張強度に及ぼす粒子分布の影響}

Fig. 5 に各試料の機械的性質を示した. 複合試料のマクロ 高度は $\mathrm{SiC}$ 粒子体積率の増加とともに上昇したが, 引張強 さ, 耐力抢よび伸びはマトリックス合金試料よりも低く, 体 積率の増加とともに低下した．破断後の破面近傍の組織を観 察したところ, マトリックス合金試料の場合, 共晶 $\mathrm{Si}$ や Fe 化合物が起点となる微小なき裂が多数観察され, さらに，き 裂は破断面から約 $5 \mathrm{~mm}$ 程度離れた広い範囲で発生してい た.このことからマトリックス試料の場合は比較的広範囲に 渡って塑性変形が生じた後に破断したものと考えられた。一 方, 複合試料では, 破断面から $1 \mathrm{~mm}$ ほどの局所範囲におい て， $\mathrm{SiC}$ 粒子凝集部抢よび $\mathrm{SiC}$ 凝集部/マトリックス界面を 基点とした比較的大きなき裂が観察された. したがって, 複 合試料においては $\mathrm{SiC}$ 粒子とマトリックス間の界面結合力 が他の晶出化合物と比較して低く, $\mathrm{SiC}$ 粒子の凝集部が応力

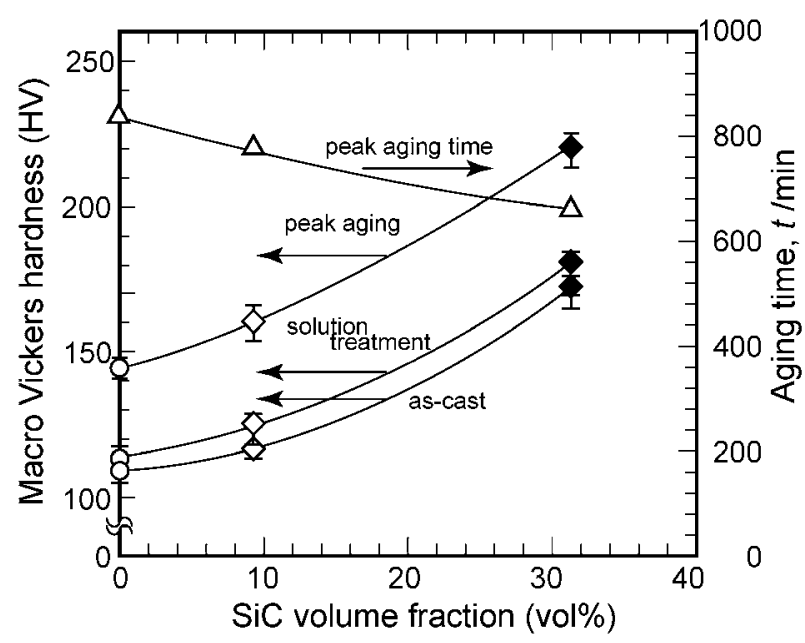

Fig. 4 Relationship between macro- Vickers hardness, peak aging time and $\mathrm{SiC}$ volume fraction at the stage of as-cast, solution treatment and peek aging. 
集中源として作用し，き裂・破断を招いたと考えられる.

\section{4 平滑材試料の疲労特性に及ぼす粒子分布の影響}

Fig. 6 に，マトリックス合金試料，9vol\%抢よび 31 vol\% $\mathrm{SiC}$ 試料の $\mathrm{S}-\mathrm{N}$ 曲線を示した。なお，図中の矢印はその荷 重に対して繰返し数 $(N)$ が $10^{7}$ 回を越えても破断しなかった ことを示す。マトリックス合金試料では $\sigma=140 \mathrm{MPa}$ 以上 の応力では $N=10^{7}$ 回以前に破断し, またその結果がばらつ いていた。一般に鋳造材では，試料内部の鋳造欠陥の大きさ や形状および位置が試料によって異なっていることがあり, それに伴い応力集中や応力分布, き裂の発生場所や停留, 成 長の挙動, ひいてはき裂発生寿命とき裂伝ぱ寿命で定義され る疲労寿命が異なることが指摘されており 16-19), 本実験の

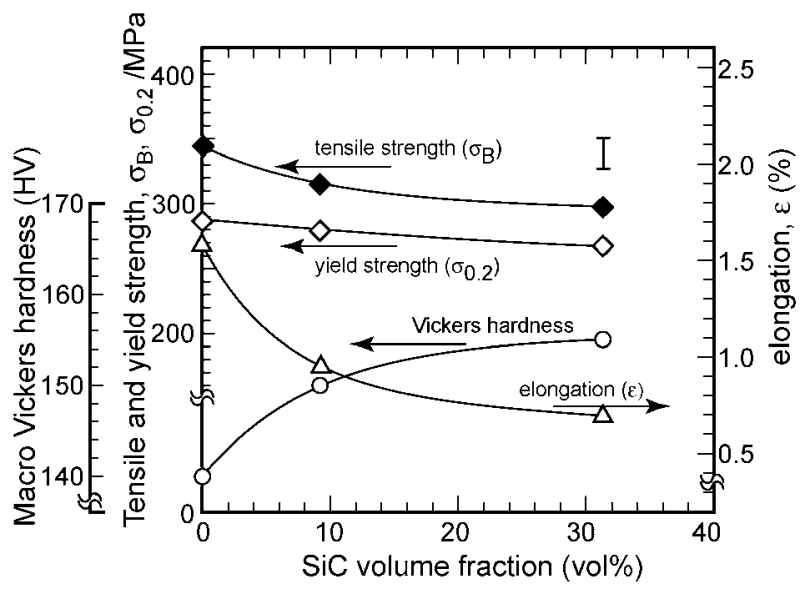

Fig. 5 Mechanical properties of matrix AC4B alloy and SiCp reinforced composite specimens.

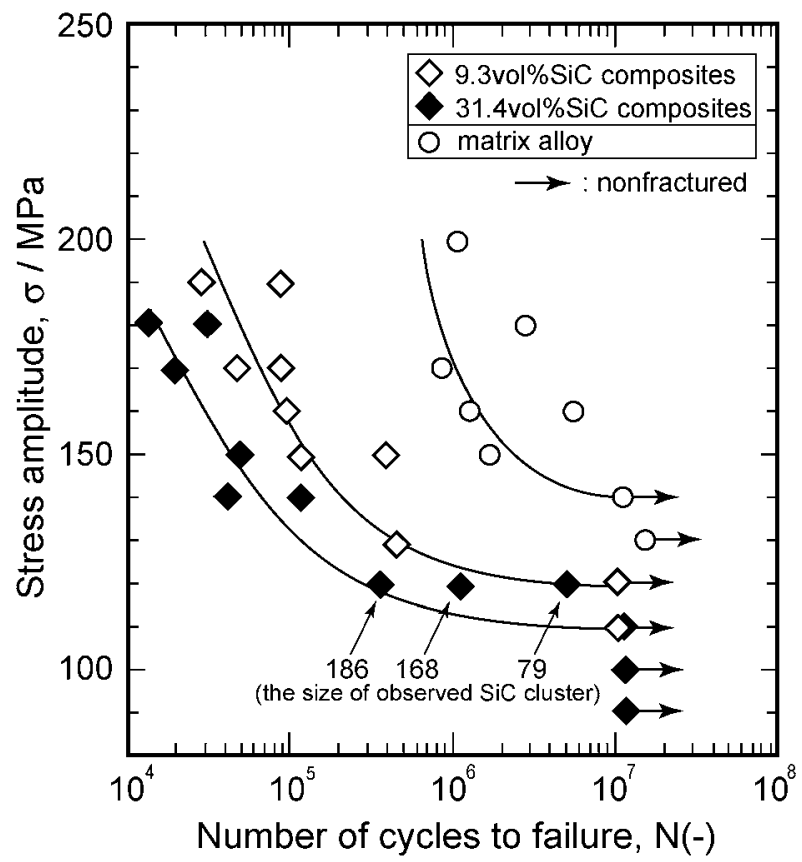

Fig. 6 Relationship between applied stress and number of cycles to failure in the rotating bending fatigue test for notch-free composites and matrix alloy specimens. The arrows in the figure show that the specimen did not rupture even with a number exceeding $10^{7}$ cycles, so experiment stopped.
場合も同様のことが生じたと考えられる， $\sigma=140 \mathrm{MPa}$ 以下 の応力では $N=10^{7}$ 回でも破断しないことから, $N=10^{7}$ 回

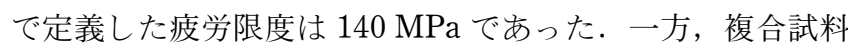
では Fig. 6 に示すように疲労限度は 9 vol\%試料で $120 \mathrm{MPa}$, $31 \mathrm{vol} \%$ 試料で $110 \mathrm{MPa}$ となり，マトリックス合金試料よ り低く，さらに $\mathrm{SiC}$ 体積率の増加とともに低下した。ま た，マトリックス試料と同様に，一つの大型試片から切り出 し，加工したにもかかわらず結果はばらついていた．試料表 面を観察したところ, マトリックス試料の場合，き裂の発生 起点にはポロシティなどの鋳造欠陥が多く観察されたが,

Fig. 2 に示す針状または複雑形状に析出した Fe 化合物から も多く発生していた。 また，き裂は初晶 $\alpha$ 中では直線的に 進んでいるが, 共晶 $\mathrm{Si}$ や, 特に Fe 化合物が存在する領域 では共晶 $\mathrm{Si}$ または $\mathrm{Fe}$ 化合物と初晶 $\alpha$ 相との界面を沿うよ うにジグザグに進展していた．また，複合試料の表面では鋳 造欠陥抢よび $\mathrm{Fe}$ 化合物だけでなく, $\mathrm{SiC}$ 粒子凝集部からの 微視的な停留き裂が多く観察された。これまで，アルミニウ ム鋳造合金の破壊起点としては, 試験片表面近傍のポロシテ ィ, 介在物, $\mathrm{Fe}$ 化合物および共晶 $\mathrm{Si}$ が考えられるとする報 告があり 20,21), 本実験の場合も，いずれの場合も破壊の起点 となっていた. 試料表面に抢ける引け巣を調査したところ, マトリックス試料では最大径が $25.0 \mu \mathrm{m}$ であったのに対し, $9 \mathrm{vol} \%$ 抢よび $31 \mathrm{vol} \% \mathrm{SiC}$ 試料ではそれぞれ $32.6 \mu \mathrm{m}$ および $48.4 \mu \mathrm{m}$ と大きくなっていた. よってポロシティの体積率の 増大は疲労限度低下の一因とは考えられる。しかし，マトリ ックス試料では $\mathrm{Fe}$ 化合物が，複合試料ではむしろ $\mathrm{SiC}$ 粒子 凝集部が大きく関与していると考えられた。 そこで，き裂の 発生状況および進展挙動を調査するために, 試験後の破断面 をSEMにより観察した.なお, 疲労試験中の圧縮時に破面 がつぶれて干渉傷が生じた試料は観察から取り除いた.

Fig. 7 (a) および Fig. 8(a)の矢印に示すように，き裂は試 料表面付近の数個所から発生し, その後, 試料内部に向かっ て放射状に進展していた。ささに，き裂の発生源には凝集し た $\mathrm{SiC}$ 粒子凝集部が確認された (Fig. 7(b), Fig. 8(b)). 凝 集部の大きさを Fig. 6 中に対応させて示したが， 31 vol\%試 料では $80 \mu \mathrm{m}$ から $190 \mu \mathrm{m}$ までの $\mathrm{SiC}$ 粒子凝集部が認めら れた. 2 つに分断された試料の破面に打いて $\mathrm{SiC}$ 粒子の凝集 部では粒子が引き抜けた跡と粒子が対応していたことより, 破壊の起点は $\mathrm{SiC}$ 凝集部と $\alpha$ 相の界面であると判断され， 複合材料に拈いてはポロシティより $\mathrm{SiC}$ 粒子凝集部が疲労 き裂発生を支配すると考えられる，また，破断面の約 10〜 20\%程度と少ないが，Fig. 7 (c) および Fig. 8 (c)に示すよう に，ファセット状破面が，また，Fig. 7(d) および Fig. 8(d) に示すストライエーション状の破面が観察されたことから, き裂は微小な破壊の繰返しで進展していると思われる.した がって複合試料の疲労き裂は試験片表面近傍の $\mathrm{SiC}$ 粒子凝 集部数ヶ所から発生し, 繰返される応力により進行し, き裂 同土が連結して進展すると考えられる.

\section{5 疲労限度に及ぼす切欠きの影響}

Fig. 9 に半径 $\rho=0.1 \mathrm{~mm}$ の切欠き加工したマトリックス 合金試料, $9 \mathrm{vol} \%$ 抢よび $31 \mathrm{vol} \% \mathrm{SiC}$ 複合試料の $\mathrm{S}-\mathrm{N}$ 曲線 

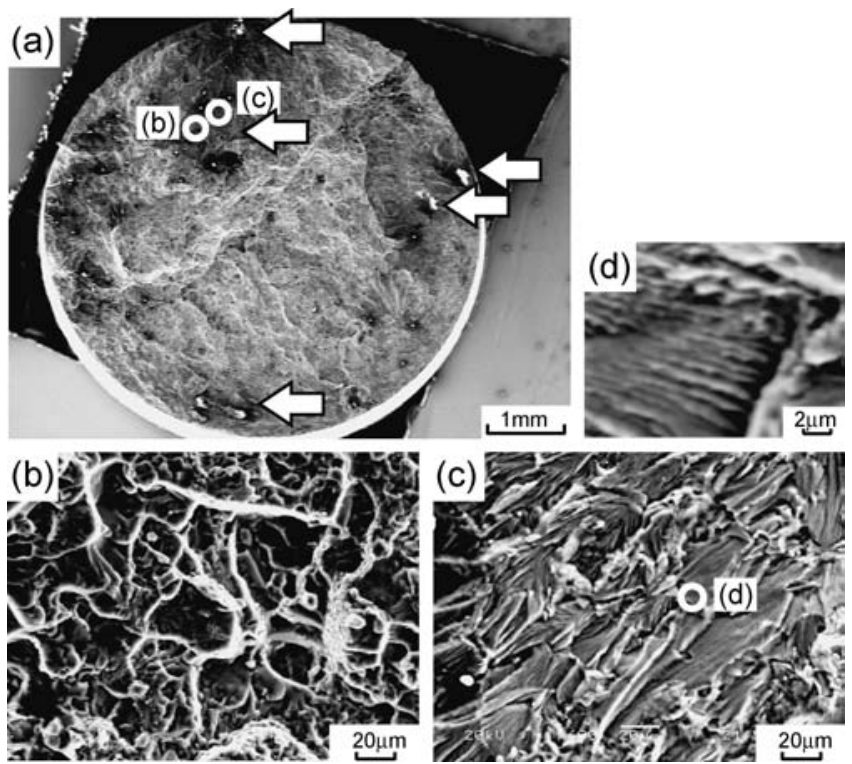

Fig. 7 Scanning electron micrographs of fractured surfaces for $9.3 \mathrm{vol} \% \mathrm{SiC} / \mathrm{AC} 4 \mathrm{~B}$ composites in applied stress of $130 \mathrm{MPa}$ (a). There are clusters of $\mathrm{SiC}$ particle (arrows in (a) and (b)), uneven fracture surface (c) and striation pattern (d) on the surface.

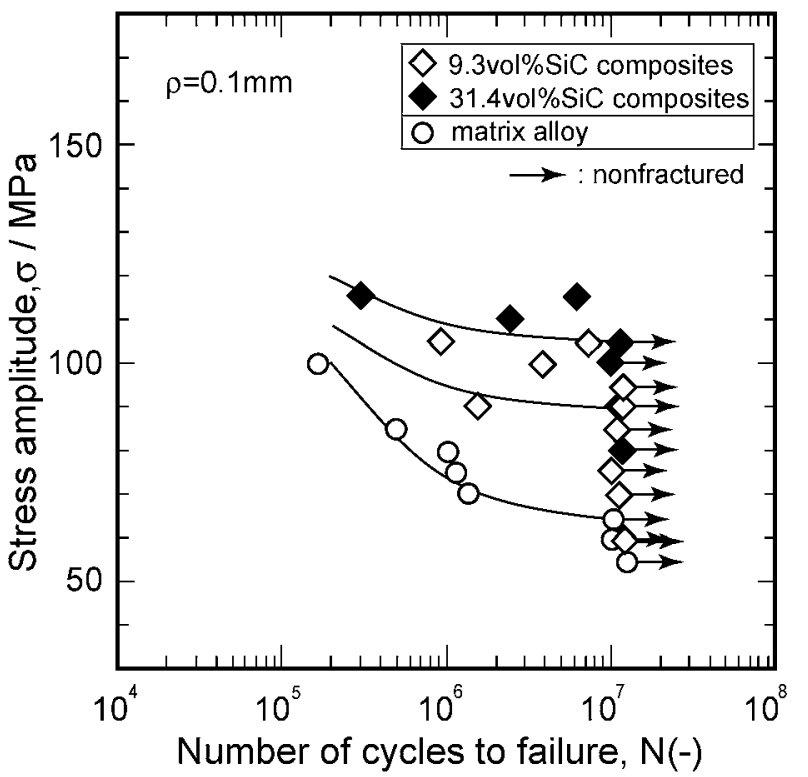

Fig. 9 Relationship between applied stress and number of cycles to failure in the rotating bending fatigue test for notched composites and matrix alloy specimens $(\rho=0.1 \mathrm{~mm})$.
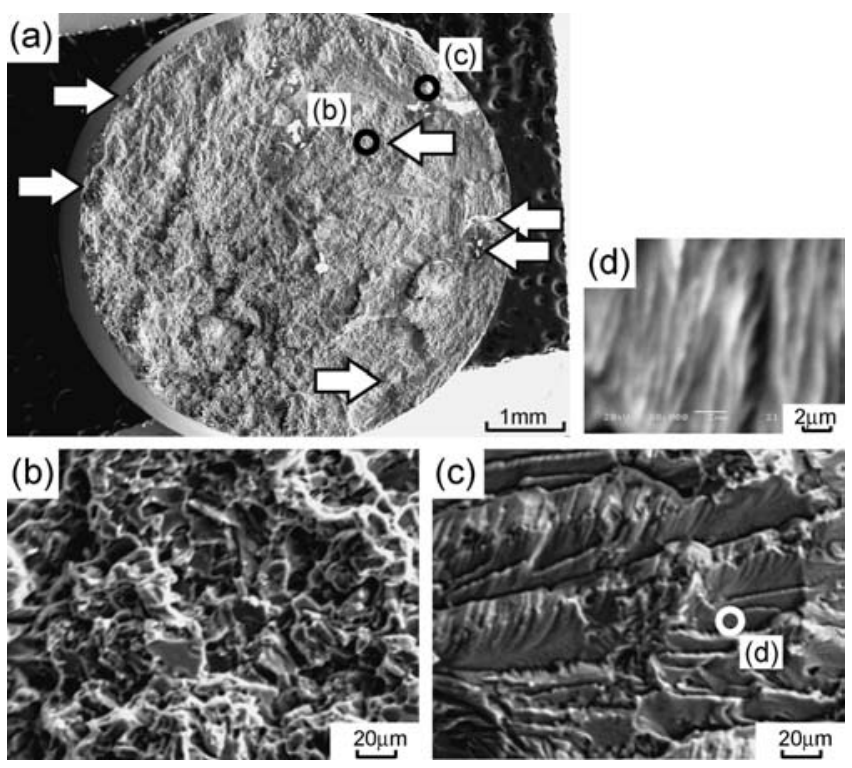

Fig. 8 Scanning electron micrographs of fractured surfaces for $31.4 \mathrm{vol} \% \mathrm{SiC} / \mathrm{AC} 4 \mathrm{~B}$ composites in applied stress of 120 $\mathrm{MPa}$.

を示す。マトリックス合金試料の場合，平滑試料と同様に設 定荷重の低下とともに $N$ は上昇したが，切欠き疲労限度は $\sigma=65 \mathrm{MPa}$ と低かった。一方，複合試料の疲労限度は 9 $\mathrm{vol} \% \mathrm{SiC}$ 試料で $95 \mathrm{MPa}, 31 \mathrm{vol} \% \mathrm{SiC}$ 試料で $105 \mathrm{MPa}$ が得 られ，平滑試料とは逆にマトリックス合金試料より高く,さ らに $\mathrm{SiC}$ 体積率が高いほど疲労限度も高かった。そこで $N$ $=10^{7}$ 回の未破断試料を観察したところ，いずれの試料も巨 視的停留き裂が観察されたが，停留き裂はマトリックス合金 試料では切欠き底表面のみに進展しており，一方，複合試料 では切欠きを中心にしているものの切欠きから離れて約 5 $\mathrm{mm}$ 幅の比較的広い範囲で, $\mathrm{SiC}$ 粒子と初晶 $\alpha$ 相との界面, あるいは粒子近傍を全周に渡ってジグザグに進展していた。 特に, $31 \mathrm{vol} \% \mathrm{SiC}$ 試料では, 切欠き底では複数の停留き裂 が複雑に絡み合っており, $\mathrm{SiC}$ 粒子によってき裂が複雑に分 岐していた。

$9 \mathrm{vol} \% \mathrm{SiC}$ 試料および $31 \mathrm{vol} \% \mathrm{SiC}$ 試料の $\rho=0.1 \mathrm{~mm}$ 切 欠き材について, 疲労破壊した破面を SEM により観察した 結果を Fig. 10 および Fig. 11 に示す. 平滑表面試料の場合 と同様に試料表面の $\mathrm{SiC}$ 粒子凝集部から複数のき裂が発生 し(Fig. 10(a) および $11(\mathrm{a})$ )，その後き裂が試料内部に向か って放射状に進展している．複合試料では，切欠き材に抢い ても特有の破面は観察されず，平滑材の破面と同様に凹凸の ある複雑な破面を呈していた．Fig. 10（b) 抢よび 11 (b)にき 裂発生部の疲労破面の一つを観察した結果を示す．9 vol\% および $31 \mathrm{vol} \% \mathrm{SiC}$ 両試料とも破壊の起点部には $\mathrm{SiC}$ 粒子凝 集部が観察され，その近傍にファセット状破面(Fig. 10 (c) および $11(\mathrm{c}))$ もわずかに観察された. その大きさはデンド ライトサイズと同程度であり，マトリックス合金試料の場合 と比較して小さい。 また，Fig. 10(d) および $11(\mathrm{~d})$ に示すス トライエーション状の破面も観察された.デンドライト間隙 には剥離した $\mathrm{SiC}$ 粒子が観察され， $\mathrm{SiC}$ 粒子によりき裂の進 展方向が変化していた．以上の観察から $\mathrm{SiC}$ 粒子凝集部で は進展するき裂が分断され，各々のき裂先端における応力集 中が緩和されて結果として生成したき裂が破壊に寄与できな くなるものと考えられる.

Fig. 12 に切欠きと負荷応力 $(\sigma)$ の関係についてまとめ た。な押，各試料の切欠きの定量化法としては，切欠き形 状. 寸法から一意的に決定される応力集中係数 $\left(K_{t}\right)^{22)}$ を用 いた。き裂が生成しても破断に至らない現象が見られたの で，き裂を発生させるための臨界応力すなわちき裂発生応力 $\left(\sigma_{w 1}\right)$, 抢よび発生したき裂が進展して試料を破壊させる臨 

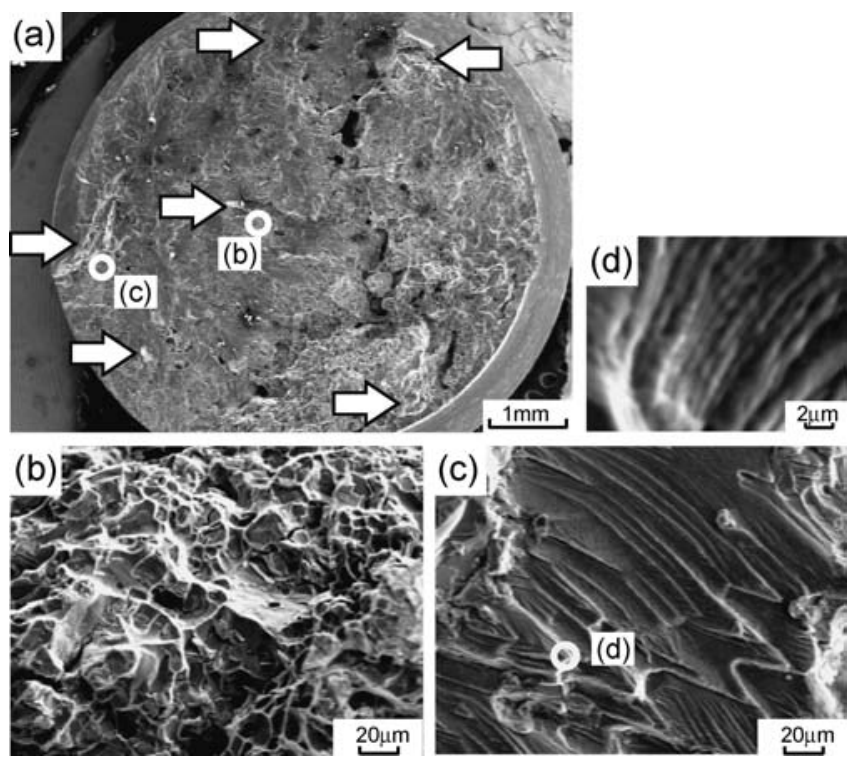

Fig. 10 Scanning electron micrographs of fractured surfaces for notched $9.3 \mathrm{vol} \% \mathrm{SiC} / \mathrm{AC} 4 \mathrm{~B}$ composites. The applied stress is $100 \mathrm{MPa}$, and notch radius is $0.1 \mathrm{~mm}$.
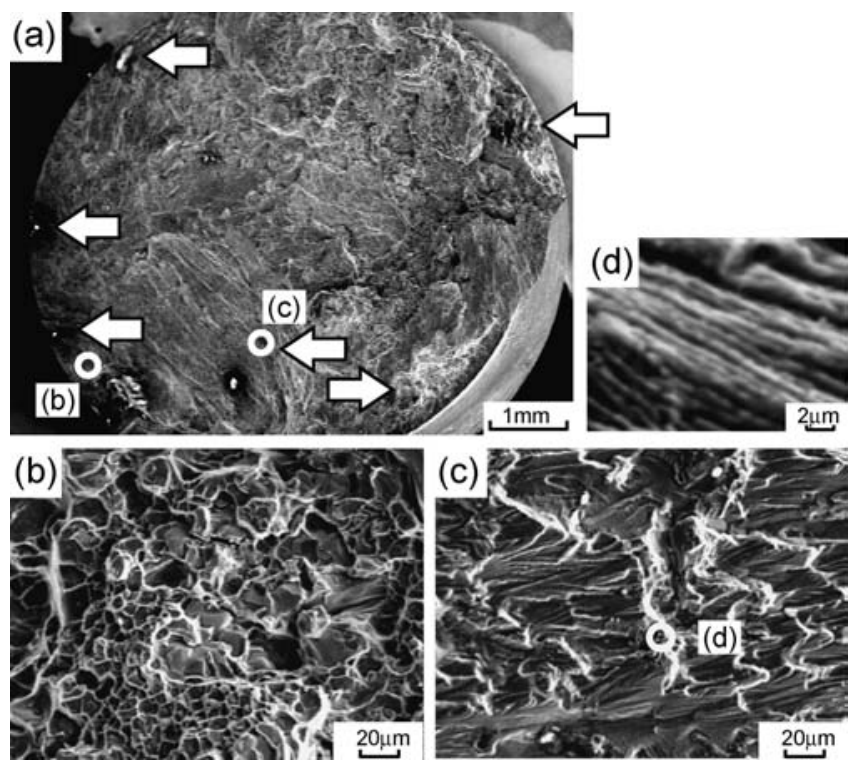

Fig. 11 Scanning electron micrographs of fractured surfaces for notched 31.4 vol\% $\mathrm{SiC} / \mathrm{AC} 4 \mathrm{~B}$ composites. The applied stress is $110 \mathrm{MPa}$, and notch radius is $0.1 \mathrm{~mm}$.

界応力すなわちき裂進展限界応力 $\left(\sigma_{w 2}\right)$ を考察した。 $\sigma_{w 1}$ は 試験終了後の試験片表面上を詳細に調査することにより決定 し，一方， $\sigma_{w 2}$ は Fig. 6 およひび Fig. 9 の S-N 曲線によって 求めた疲労限度を用いた。平滑試料 $\left(K_{t}=1\right)$ に打いては, 前 述のようにマトリックス合金試料の疲労限度が $140 \mathrm{MPa}$ と 最も高く, 複合試料の值が $110 \sim 120 \mathrm{MPa}$ と低かった。 た，いずれも $\sigma_{w 1}$ と $\sigma_{w 2}$ には明確な差はみられなかった ${ }^{22)}$. 一方, 切欠き半径が $0.1 \mathrm{~mm}\left(K_{t}=3.76\right)$ の場合, $\sigma_{w 1}$ は 55 $\mathrm{MPa}$ と著しく低くなった。いずれの試料も同じ $\sigma_{w 1}$ を示し ているが，き裂は切欠きの存在により強制的に導入されるこ とと，鋳造欠陥と共に分散する $\mathrm{Fe}$ 化合物や，複合試料では $\mathrm{SiC}$ 粒子もき裂の発生点となることから，その発生臨界値

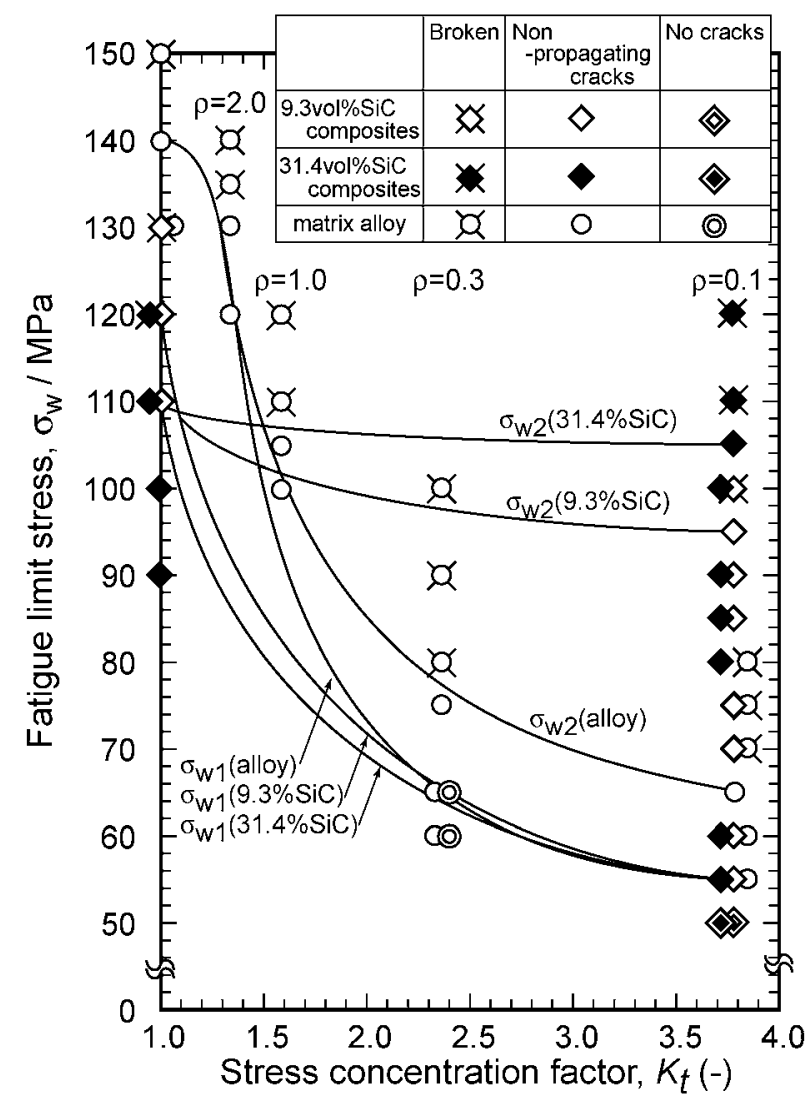

Fig. 12 Relationship between the fatigue limit stress and the stress concentration factor.

$\sigma_{w 1}$ は本実験の条件では試料間の差は見られなかったと考え られる。一方， $\sigma_{w 2}$ はマトリックス試料については $K_{t}$ の上 昇とともに低下するが，複合試料では $K_{t}$ が増加してもほと んど変化せず，9 vol\% $\mathrm{SiC}$ 試料で $95 \mathrm{MPa}, 31 \mathrm{vol} \% \mathrm{SiC}$ 試 料で $105 \mathrm{MPa}$ を示し，特に $31 \mathrm{vol} \% \mathrm{SiC}$ 試料では平滑材の 疲労限度 $(110 \mathrm{MPa})$ とほぼ同等の值であった。 $\left(K_{t}=3.78\right.$ に 抢ける各試料の $\sigma_{w 1}$ 抢よび $\sigma_{w 2}$ を粒子体積率との関係で Fig. 13 に示したが， $\sigma_{w 1}$ は粒子体積率に依存せずほぼ一定である のに対し， $\sigma_{w 2}$ は $\mathrm{SiC}$ 粒子体積率の増加とともに上昇し, $\sigma_{w 1}$ と $\sigma_{w 2}$ の間すなわち, き裂が生じても破断に至らない領 域が拡大された. さらに, 線形切欠き力学 22 に基づき $\sigma_{w 1}$ 掠 よび $\sigma_{w 2}$ を平滑材の疲労限度 $\left(\sigma_{w 0}\right)$ と応力集中係数 $K_{t}$ の関係 として整理して各試料の切欠き感度を評価した. Fig. 14 に 示すように, マトリックス試料の $\sigma_{w 1}$ 抢よび $\sigma_{w 2}$ はほぼ 1 を 示すのに対し, 複合試料の $\sigma_{w 2}$ は 3 以上の高い值を示した. このことから複合試料では, き裂伝ぱに扔いては応力集中係 数の大きさによらず切欠き感度は鈍くなると考えられる.

Fig. 15 に，未複合試料抢よび複合試料の疲労破面を $45^{\circ}$ 方向から観察した結果抢よび破壊の模式図を示す。マトリッ クス合金試料では，試験片内部方向へのき裂が比較的直線に 進展している(Fig. 15 (b))．またき裂は切欠き底表面に発生 し，それらが連結して成長して破断に至っている，一方，複 合材では Fig. 15 (c)，（d）に示すように，疲労き裂は切欠き 部以外の $\mathrm{SiC}$ 粒子凝集部からも多数発生し, 非常に凹凸の 激しい複雑な破面を形成している。この傾向は $31 \mathrm{vol} \% \mathrm{SiC}$ 試料の方が大きく, き裂の進展方向の変化や分岐の頻度が高 


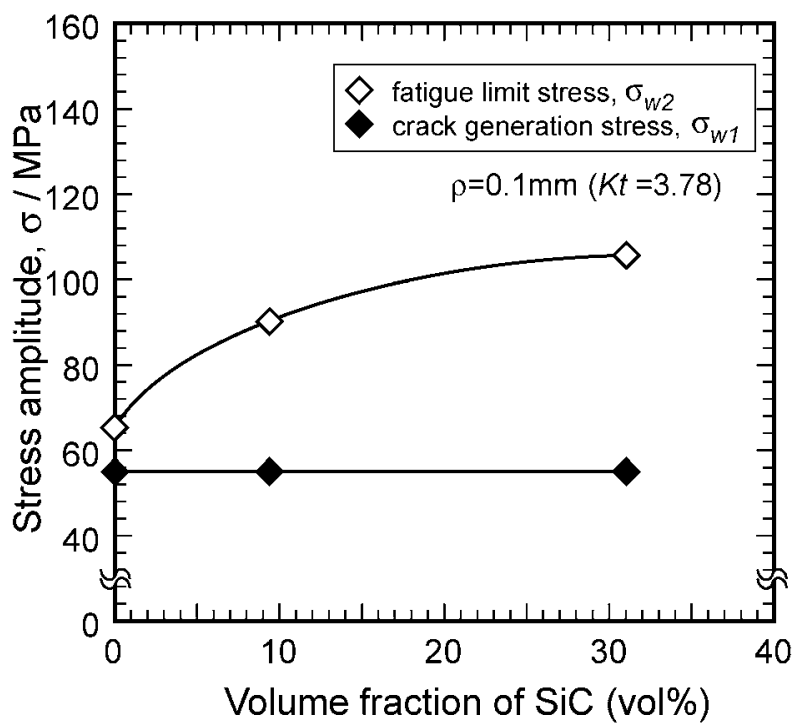

Fig. $13 \mathrm{SiC}$ volume fraction dependence of the fatigue limit stress and the crack generation stress.

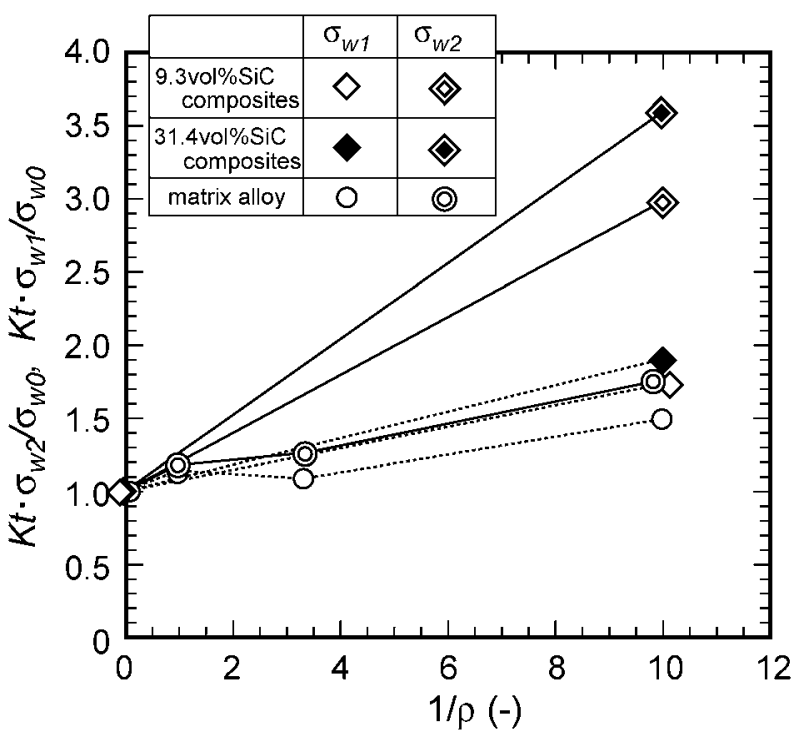

Fig. 14 Relationship between $K_{t} \cdot \sigma_{w 2} / \sigma_{w 0}, K_{t} \cdot \sigma_{w 1} / \sigma_{w 0}$ and $1 / \rho$.
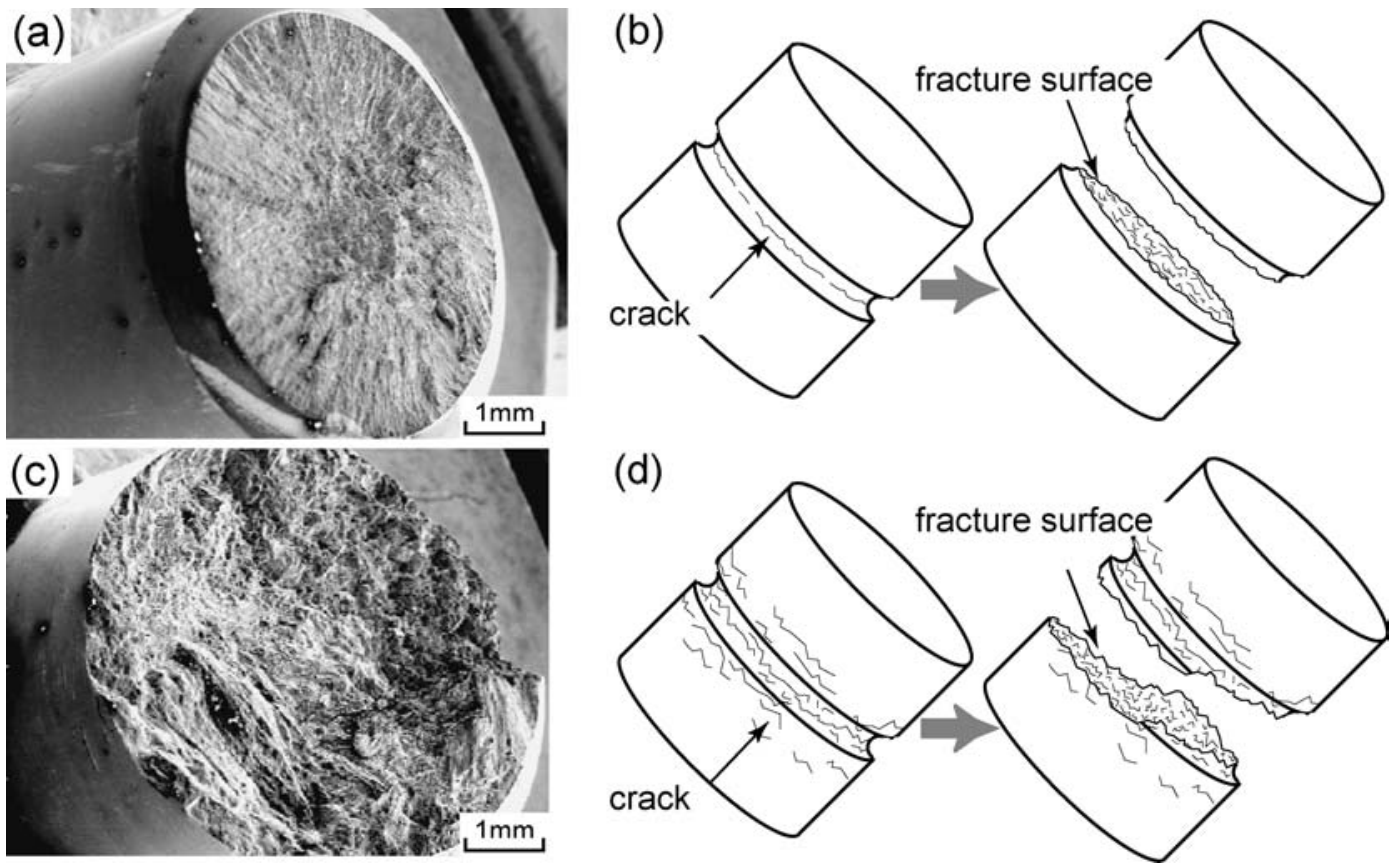

Fig. 15 Scanning electron micrographs of the fatigue fracture surfaces for unreinforced AC4B alloy (a) and $31.4 \mathrm{vol} \% \mathrm{SiC}$ reinforced composites (c) at 45-degrees angle, and schematic illustrations of fracture mechanisms in the unreinforced alloys (b) and composites (d).

い. $\mathrm{SiC}$ 粒子凝集部がき裂進展の抵抗となる理由は，今後詳 細な調査が必要であるが， $\mathrm{SiC}$ 粒子近傍では，上述するよう にマトリックス合金との熱膨張係数の差により導入された高 密度に存在する転位や, 析出 $\lambda^{\prime}$ 相打よび $\theta^{\prime}$ 相の強度上昇 が，き裂周辺の加工硬化抢よび塑性誘起き裂閉口を助長し， さらに，き裂が分岐することによるき裂先端での応力集中緩 和，得られる凹凸の激しい破面により生ずる破面粗さ誘起き 裂閉口等も加えて，き裂の伝ぱ，進展および結合を妨げ，き 裂伝ぱ抵抗ひいては $\sigma_{w 2}$ を向上させたと考えられる.

\section{4. 結言}

加圧溶浸法, 溶湯攪拌法を組み合わせて $\mathrm{SiC}$ 粒子分散 AC4B 複合材料を作成し，組織形成過程に及ぼす分散粒子の 影響を調査するとともに切欠き疲労試験を行い, 疲労特性に 及ぼす凝固組織および粒子分布の影響を切欠き効果と関連づ けて調査した。その結果次のような結論を得た。

（1）加圧溶浸法，溶湯覺拌法を組み合わせることにより， $\mathrm{SiC}$ 粒子を任意の体積率で比較的均一に分散することができ る. 
（2）複合材料においてもマトリックス合金と同様に時効硬 化が生じ， $\mathrm{SiC}$ 体積率の増加とともにその硬化量も上昇する.

(3) $\mathrm{SiC} / \mathrm{AC} 4 \mathrm{~B}$ 合金複合材料に打いては，平滑または応 力集中係数が低い場合, $\mathrm{SiC}$ 体積率の増加とともに疲労限度 は低下する。これは $\mathrm{SiC}$ 粒子凝集部に拈いて応力が集中 し，粒子/マトリックス合金界面でき裂抢よび剥離が生じる ためと考えられる.

（4）切欠き半径が小さく, 応力集中係数が高い場合は, $\mathrm{SiC}$ 体積率の増加とともにき裂進展限界応力は向上する.こ れはき裂の進展が $\mathrm{SiC}$ 粒子により分岐され，き裂伝ぱ抵抗 が向上したためと考えられる. 複合材料ではき裂は分散した $\mathrm{SiC}$ 粒子凝集部から発生・伝ぱし, 切欠きは疲労限度にほと んど影響を及ぼさないと考えられる。

本研究における回転曲げ疲労試験は九州大学工学研究院機 械科学部門の装置を使用して行われた. 疲労試験に際してご 協力を頂いた野口博司教授, ならびに試料の精密加工にご協 力を頂いた中江 洋技官に深く感謝致します.

\section{文献}

1) A. P. Sannio and H. J. Rack: Wear 189(1995) 1-19.

2) T. Hikosaka, K. Miki and Y. Nishida: J. JFES 61(1989) 780786.
3) A. Kawabe, A. Oshida, T. Kobayashi and H. Toda: J. JILM 49 (1999) 149-154.

4) A. Watanabe, H. Watanabe, K. Ohori and Y. Takeuchi: J. JILM 38(1988) 626-632.

5) P. K. Rohatgi, R. Asthana and S. Das: Int. Met. Rev. 31 (1986) 115-139.

6) S. V. Nair, J. K. Tien and R. C. Bates: Int. Met. Rev. 30 (1985) 275-290.

7) T. S. Srivatsan and M. Al-Hajri: Composites B33(2002) 391404.

8) Z. Z. Chen and K. Tokaji: Mater. Lett. 58(2004) 2314-2321.

9) N. E. Bekheet, R. M. Gadelrab, M. F. Salah and A. N. Abd ElAzim: Mater. and Design 23(2002) 153-159.

10) L. H. Qian, Z. G. Wang, H. Toda and T. Kobayashi: Mater. Sci. Eng. A357 (2003) 240-247.

11) H.-G. Kang, M. Kida, H. Miyahara and K. Ogi: Int. J. Cast Met. Res. 15(2002) 1-7.

12) S. Ikeno, K. Kawashima, K. Matsuda, H. Anada and S. Tada: J. JILM 41(1991) 752-758.

13) R. J. Arsenault and N. Shi: Mater. Sci. Eng. 81(1986) 175-187.

14) R. J. Arsenault and R. M. Fisher: Scr. Metall. 17(1983) 67-71.

15) M. Vogelsang, R. J. Arsenault and R. M. Fisher: Metall. Trans. A 17A(1986) 379-389.

16) Y. Maruno, H. Miyahara, H. Noguchi and K. Ogi: J. Jpn Inst. Met. 45(2004) 839-843.

17) H. Kobayashi: Fracture Mechanics, (KYORITU, 1993) pp. 137146.

18) T. Araki and S. Horibe: Fatigue of Metallic Materials, (YOKENDO, 1984) pp. 46-70

19) T. Kobayashi, T. Ito, H. J. Kim and S. Kitaoka: J. JILM 46(1996) 437-443.

20) E. Kato: J. JILM 45(1995) 9-14.

21) Y. Kuroki, T. Tanaka, T. Sato and A. Kamio: J. JILM 50 (2000) 116-120.

22) H. Nisitani: JSME 55-516 A(1989) 1733-1739. 